\title{
Effect of varying protein levels on growth and digestive enzyme activities of pengba Osteobrama belangeri (Valenciennes, 1844)
}

\author{
R. RAMESH ${ }^{1}$, K. DUBE ${ }^{2}$, A. K. REDDY ${ }^{2}$, P. V. RANGACHARYULU ${ }^{1}$, \\ G. VENKATESHWARLU ${ }^{2}$ AND P. JAYASANKAR ${ }^{3}$ \\ ${ }^{1}$ Regional Research Centre of ICAR-Central Institute of Freshwater Aauaculture, Fish Seed Farm, Penamaluru \\ Poranki P. O., Vijayawada - 521 137, Andhra Pradesh, India \\ ${ }^{2}$ ICAR-Central Institute of Fisheries Education, Panch Marg, Off Yari Road, Versova, Andheri (West) \\ Mumbai - 400 061, Maharashtra, India \\ ${ }^{3}$ ICAR-Central Institute of Freshwater Aquaculture, Kausalyaganga, Bhubaneswar - 751 002, Odisha, India \\ e-mail: rathodcifa@gmail.com
}

\begin{abstract}
Pengba, Osteobrama belangeri (Valenciennes, 1844) is considered as one of the candidate species for diversification of aquaculture. However, only scanty information is available on its nutrient requirements. Hence, the present study was conducted on growth and digestive enzyme activities of pengba fry in response to different dietary protein levels. Six semi-purified isocaloric diets were formulated with different levels of protein at 5\% increments $(25,30,35,40,45$ and $50 \%)$ and fed to different groups of pengba fry for a period of 60 days. Survival of fish was significantly influenced by different protein levels $(\mathrm{p}<0.05)$. The highest weight gain $\%$ and specific growth rate $\left(4.17 \%\right.$ day $\left.^{-1}\right)$ was obtained at $45 \%$ protein level which thereafter declined. The best feed conversion ratio (1.46) was observed at $45 \%$ protein level and the highest protein efficiency ratio (2.14) was obtained at $25 \%$ protein level with significant difference $(\mathrm{p}<0.05)$. The crude protein content of fish was significantly affected by dietary protein levels $(\mathrm{p}<0.05)$ and highest was recorded at $45 \%$ protein diet. Moisture, ether extract and ash content did not show significant $(\mathrm{p}>0.05)$ variation among dietary treatments. The activity of proteolytic enzymes (proteases, typsin and chymotrypsin) and acid phosphatase were signicantly $(\mathrm{p}<0.05)$ enhanced by dietary protein levels up to $45 \%$, which were found to decline thereafter. Amylase activity was significantly decreased as protein levels increased in the diet. Lipase and alkaline phosphatase activities were not influenced by dietary protein levels. In the present study, penbga fry fed with $45 \%$ protein diet, showed the best growth performance and highest digestive enzyme activities. The activity of digestive enzymes in the gut clearly demonstrated that the proteolytic enzymes are activated in response to dietary protein utilisation and also revealed that pengba fry may require high protein (45\%) diet for better growth and survival. Second order polynomial regression analysis revealed that the maximum protein requirement of pengba fry was $45.1 \%\left(\mathrm{r}^{2}=0.90\right)$. The findings of the study is expected to have significant implications for feed development for pengba aquaculture.
\end{abstract}

Keywords: Digestive enzymes, Growth, Osteobrama belangeri, Pengba, Protein levels

Protein is very much essential for growth and to maintain the metabolic activities of fish (Wilson and Halver, 1986). The essential amino acids (EAA) and non-essential amino acids (NEAA) incorporated in the fish feed help to synthesise body protein and provide energy for metabolic activity (Lovell, 1989; Kaushik et al., 1995). Studies on protein requirements of carps have been undertaken by many workers using casein based synthetic diets (Mahanta et al., 2008; Ismat et al., 2013). Adequate amino acid levels required to maximise the growth of fish is supplied through optimum dietary protein levels (Siddiqui and Khan, 2009). Excess protein in the diet increases the production cost and can lead to pollution of pond environment. Therefore, it is necessary to optimise the protein levels in the fish diets considering economics and environmental perspective (Siddiqui and Khan, 2009; Akpinar et al., 2012).

The activities of digestive enzymes may vary among different fish species, which mainly depends on age of fish, quantity and composition of the diet (Peres et al., 1998). Digestive enzyme activities of different fish species have been reported with varying levels of dietary proteins (Debnath et al., 2007; Mahanta et al., 2008; Bhilave et al., 2014). Activities of digestive enzymes and nutrient utilisation are the key factors that help in standardisation of fish feeding protocols (Doos Ali Vand et al., 2014). Patterns of digestive enzyme activity can reflect the feeding habits as well as digestive capacity of fish and these activities are modulated based on the source, quality and quantity of the feed (Debnath 
et al., 2007; Gonza'lez-Fe'lix et al., 2010). Further, it helps in predicting the possiblites of utilising different nutrients in the diet of fish (Hofer and Kock, 1989).

Pengba, Osteobrama belangeri (Valenciennes, 1844), is a minor carp which belongs to cyprinid group and it is distributed in the rivers and lakes of Asian countries like Yunnan Province of China, Myanmar and India. Pengba is regarded as the state fish of Manipur. The fish has been identified as a potential candidate species for diversification of aquaculture in India as it is a preferred species due to its high quality meat. However, low survival of juveniles is one of the major limitations for its adoption. Earlier, information on food and feeding habits and growth in relation to dietary protein utilisation of pengba was reported by Basudha et al. $(1999,2001)$. However, there is no information available on effect of different protein levels on the digestive pattern of this species. The survival and growth of fish mainly depend on nutritionally balanced feed and knowledge on digestive physiology is essential to understand nutritional strategies for the formulation of such fish diets. With this background, the present study was carried out in order to study the effect of varying protein levels on growth performance and to assess the digestive enzymes activity of pengba fry in response to protein utilisation.

Six isocaloric experimental diets were prepared with different levels of protein viz. 25, 30, 35, 40, 45 and 50\%. List of ingredients and proximate composition of the diets is presented in Table 1. Semi-purified diets were used in the study with casein and gelatin as protein source (maintained at a ratio of 4:1) and sunflower oil and fish oil were used as lipid source in equal proportions. Energy was adjusted with dextrin and starch. $\alpha$-Cellulose was used as filler component.

Three hundred sixty nos. (20 per tank) of pengba fry (mean weight of $0.45 \pm 0.01 \mathrm{~g}$ ) were stocked in 18 tanks of 1001 capacity. Each diet was randomly assigned to triplicate tanks. Fish were fed initially at $6 \%$ of body weight and later reduced to $3 \%$ of body weight. Experimental feeding was done for a period of 60 days which was given daily at 0900 and $1700 \mathrm{hrs}$. All the tanks were siphoned to remove waste materials to maintain healthy environment in the tank and $1 / 4^{\text {th }}$ water exchange was done every day. All the water quality parameters were recorded at every fortnight. The fish were starved for $24 \mathrm{~h}$ before sampling.

Experimental diets and fish carcass were analysed as per AOAC (2003) for proximate composition. Moisture content was analysed by oven drying at $105^{\circ} \mathrm{C}$ for $24 \mathrm{~h}$; crude protein content was determined by Kjeldahl method (Nx6.25); ether extract was estimated with diethyl ether for $6 \mathrm{~h}$ in a soxhlet apparatus. Muffle furnace was used to estimate the ash content from moisture free samples at $600^{\circ} \mathrm{C}$ for $12 \mathrm{~h}$. The nitrogen free extract (NFE) was estimated by subtracting the contents of protein, fat, ash and moisture.

Growth and FCR was determined using the following formulae:

Survival (\%) $=100 \mathrm{x}$ Final no. of fish (FN)/ Initial no.of fish (IN)

Weightgain $(\%)=[$ Weight of fish at final day $(\mathrm{FW})$-Initial weight offish (IW] / Initial weight) x 100

Table 1. Ingredients used and nutrient composition of the experimental feeds ( $\%$ dry matter)

\begin{tabular}{lllllll}
\hline \multirow{2}{*}{ Ingredient composition } & \multicolumn{5}{l}{ Protein levels (\%) } \\
\cline { 2 - 7 } & 25 & 30 & 35 & 40 & 45 & 50 \\
\hline Casein & 23.9 & 28.68 & 33.46 & 38.85 & 43.39 & 48.66 \\
Gelatin & 6 & 7.2 & 8.4 & 9.1 & 10.5 & 11.3 \\
Starch & 16.65 & 14.85 & 13.5 & 12.5 & 11.23 & 9.45 \\
$\alpha$-cellulose & 8.35 & 9.15 & 9.5 & 10.5 & 10.77 & 11.55 \\
Dextrin & 35.1 & 30.12 & 25.14 & 19.05 & 14.11 & 9.04 \\
CMC & 2 & 2 & 2 & 2 & 2 & 2 \\
Fish oil & 3 & 3 & 3 & 3 & 3 & 3 \\
Sunflower oil & 3 & 3 & 3 & 3 & 3 & 3 \\
Vitamin-mineral mix & 2 & 2 & 2 & 2 & 2 & 2 \\
\hline Proximate composition & 2 & & & & 96.02 & 96.11 \\
\hline Dry matter & & 94.37 & 93.71 & 95.27 & 96.02 & 50.01 \\
Crude protein & 94.76 & 30.49 & 34.98 & 40.66 & 44.94 & 6.16 \\
Ether extract & 25.02 & 6.30 & 6.53 & 5.95 & 6.18 & 5.1 \\
Ash content & 6.14 & 5.67 & 6.01 & 5.04 & 5.9 & 26.23 \\
Nitrogen free extract & 5.18 & 41.91 & 37.19 & 34.52 & 32.3 & \\
\hline
\end{tabular}

${ }^{1}$ Carboxy methyl cellulose

${ }^{2}$ Vitamin-mineral mix (Debnath et al., 2007) 
Specific growth rate $\left(\mathrm{SGR}, \%\right.$ day $\left.^{-1}\right)=[\ln \mathrm{FW}-\ln \mathrm{IW}] /$ No. of culture days $\mathrm{x} 100$

Food conversion ratio $(\mathrm{FCR})=$ Dry feed intake $(\mathrm{g}) /$ Wet weight gain $(\mathrm{g})$

Feed efficiency ratio $($ FER $)=$ Net wet weight gain $(\mathrm{g}) /$ Dry feed intake $(\mathrm{g})$

Protein efficiency ratio $($ PER $)=($ Final wieight - Initial weight $) /($ Total feed consumed by fish $\mathrm{x}$ Protein level in the diet).

In each treatment, six fishes were used for the enzyme analysis and their intestine were dissected and frozen immediately at $-20^{\circ} \mathrm{C}$ for enzyme assays following standard protocol (Debnath et al., 2007).

The activity of proteolytic enzyme (proteases, trypsin and chymotrypsin) was estimated by the casein digestion method of Kunitz (1947). Lipase activity was determined based on Cherry and Crandell (1932), whereas, starch solution was used as substrate for the analysis of amylase (Rick and Stegbauer, 1974). In addition, Garen and Levinthal (1960) method was used to determine the activities of alkaline phosphatase (ALP) and acid phosphatase (ACP).

One-way analysis of variance (ANOVA) was used for data analysis. Duncan's multiple range test (DMRT) was performed to measure significant difference between the treatments (SPSS, Version 16.0).

The observations of final weight, survival, weight gain $\%$ and SGR of fish fed with different treatments are given in the Table 2. Average weight gain percentage was significantly $(\mathrm{p}<0.05)$ higher in fish fed with $45 \%$ of protein level and lowest was found at $25 \%$ dietary protein. The highest SGR $\left(4.17 \pm 0.01 \%\right.$ day $\left.^{-1}\right)$ was noticed with $45 \%$ of protein diet and lowest $\left(3.34 \pm 0.01 \%\right.$ day $\left.^{-1}\right)$ was obsereved with $25 \%$ protein diet. The final weights, weight gain $\%$ and SGR increased significantly $(\mathrm{p}<0.05)$ with increase in dietary protein levels upto $45 \%$ and thereafter decreased. The survival rate varied from 72.45 to $89.42 \%$ and significantly affected $(\mathrm{p}<0.05)$ by dietary protein levels. The second order polynomial regression analysis $\left(y=-0.002 x^{2}+0.179 x+0.06\right.$;
$\left.\mathrm{R}^{2}=0.90\right)$ showed that the optimum protein levels to achieve high growth rate of pengba fry was $45.1 \%$ (Fig. 1).

Significant difference $(\mathrm{p}<0.05)$ was observed between the treatments in response to the feed utilisation parameters (FCR and PER) (Table 2). The best FCR value (1.46 \pm 0.01$)$ was found in fish fed $45 \%$ protein level followed by $40 \%$ protein with no significant difference $(\mathrm{p}>0.05)$ between these two treatments. The highest feed efficiency was observed with $45 \%$ dietary protein which was similar $(\mathrm{p}>0.05)$ to the $40 \%$ protein level, but was significantly $(\mathrm{p}<0.05)$ higher compared to other dietary treatments. As dietary protein level increased, there was significant decrease $(\mathrm{p}<0.05)$ in the PER value.

Carcass composition of fish was influenced by the different protein levels (Table 3). Crude protein, moisture, ether extract and ash content at different dietary protein levels were significantly different $(\mathrm{p}<0.05)$. The moisture content of fish was not significantly ( $p>0.05$ ) different among the dietary treatments. Crude protein content $(14.95 \pm 0.01 \%)$ was found highest in fish fed with $45 \%$ of dietary protein level and lowest $(12.83 \pm 0.02 \%)$ was observed in $25 \%$ protein level.

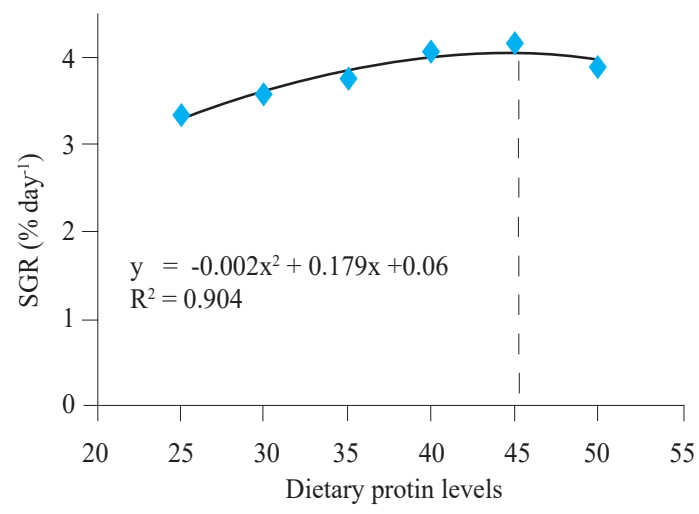

Fig. 1. Estimation of dietary protein requirement of Osteobrama belangeri fry by second order polynomial regression analysis

Table 2. Growth, survival rate and feed parameters of Osteobrama belangeri fed at different protein levels

\begin{tabular}{lllllll}
\hline \multirow{2}{*}{ Parameters } & \multicolumn{5}{c}{ Protein levels (\%) } \\
\cline { 2 - 7 } & 25 & 30 & 35 & 40 & 45 & 50 \\
\hline Initial weight (g) & $0.45 \pm 0.01$ & $0.45 \pm 0.01$ & $0.45 \pm 0.01$ & $0.45 \pm 0.01$ & $0.45+0.01$ & $0.45 \pm 0.01$ \\
Final weight (g) & $3.34 \pm 0.02^{\mathrm{a}}$ & $3.85 \pm 0.04^{\mathrm{b}}$ & $4.27 \pm 0.08^{\mathrm{c}}$ & $5.18 \pm 0.04^{\mathrm{e}}$ & $5.51 \pm 0.04^{\mathrm{f}}$ & $4.69 \pm 0.03^{\mathrm{d}}$ \\
Weight gain (\%) & $643.70 \pm 6.58^{\mathrm{a}}$ & $755.56 \pm 10.18^{\mathrm{b}}$ & $850.37 \pm 19.64^{\mathrm{c}}$ & $1052.60 \pm 9.72^{\mathrm{e}}$ & $1124.40 \pm 8.98^{\mathrm{f}}$ & $943.70 \pm 7.06^{\mathrm{d}}$ \\
SGR (\% day $\left.{ }^{-1}\right)$ & $3.34 \pm 0.01^{\mathrm{a}}$ & $3.57 \pm 0.01^{\mathrm{b}}$ & $3.75 \pm 0.03^{\mathrm{c}}$ & $4.07 \pm 0.01^{\mathrm{e}}$ & $4.17 \pm 0.01^{\mathrm{f}}$ & $3.90 \pm 0.01^{\mathrm{d}}$ \\
FCR & $1.86 \pm 0.02^{\mathrm{c}}$ & $1.73 \pm 0.01^{\mathrm{b}}$ & $1.72 \pm 0.04^{\mathrm{b}}$ & $1.50 \pm 0.01^{\mathrm{a}}$ & $1.46 \pm 0.01^{\mathrm{a}}$ & $1.68 \pm 0.02^{\mathrm{b}}$ \\
FER & $0.53 \pm 0.01^{\mathrm{a}}$ & $0.57 \pm 0.01^{\mathrm{b}}$ & $0.58 \pm 0.01^{\mathrm{b}}$ & $0.66 \pm 0.01^{\mathrm{c}}$ & $0.68 \pm 0.01^{\mathrm{c}}$ & $0.59 \pm 0.01^{\mathrm{b}}$ \\
PER & $2.14 \pm 0.07^{\mathrm{e}}$ & $1.92 \pm 0.04^{\mathrm{d}}$ & $1.66 \pm 0.03^{\mathrm{c}}$ & $1.65 \pm 0.02^{\mathrm{c}}$ & $1.52 \pm 0.02^{\mathrm{b}}$ & $1.18 \pm 0.02^{\mathrm{a}}$ \\
Survival rate (\%) & $72.45 \pm 0.05^{\mathrm{a}}$ & $78.36 \pm 0.31^{\mathrm{b}}$ & $79.47 \pm 0.22^{\mathrm{c}}$ & $86.23 \pm 0.14^{\mathrm{e}}$ & $89.42 \pm 0.09^{\mathrm{f}}$ & $82.75 \pm 0.23^{\mathrm{d}}$ \\
\hline
\end{tabular}

Results are presented as mean \pm SE $(n=3)$. Mean values with different superscripts in the same row are significantly different $(\mathrm{p}<0.05)$ 
Table 3. Proximate composition of Osteobrama belangeri fed at different dietary protein levels (\% wet weight basis)

\begin{tabular}{|c|c|c|c|c|c|c|c|}
\hline \multirow{2}{*}{ Nutrient composition } & \multicolumn{7}{|c|}{ Protein levels (\%) } \\
\hline & Initial & 25 & 30 & 35 & 40 & 45 & 50 \\
\hline Moisture & $79.6 \pm 0.06$ & $79.02 \pm 0.01^{\mathrm{a}}$ & $78.89 \pm 0.01^{\mathrm{a}}$ & $78.65 \pm 0.02^{\mathrm{a}}$ & $78.32 \pm 0.04^{\mathrm{a}}$ & $78.61 \pm 0.14^{\mathrm{a}}$ & $78.33 \pm 0.05^{\mathrm{a}}$ \\
\hline Crude protein & $12.76 \pm 0.02$ & $12.83 \pm 0.02^{\mathrm{a}}$ & $13.50 \pm 0.03^{b}$ & $13.94 \pm 0.02^{\mathrm{d}}$ & $14.12 \pm 0.01^{\mathrm{e}}$ & $14.95 \pm 0.01^{\mathrm{f}}$ & $13.62 \pm 0.01^{\mathrm{c}}$ \\
\hline Ether extract & $1.94 \pm 0.03$ & $2.57 \pm 0.01^{\mathrm{a}}$ & $2.42 \pm 0.01^{\mathrm{a}}$ & $2.34 \pm 0.02^{\mathrm{a}}$ & $2.25 \pm 0.02^{\mathrm{a}}$ & $2.04 \pm 0.01^{\mathrm{a}}$ & $2.17 \pm 0.01^{\mathrm{a}}$ \\
\hline Ash & $3.01 \pm 0.02$ & $3.72 \pm 0.01^{\mathrm{a}}$ & $3.53 \pm 0.01^{\mathrm{a}}$ & $3.61 \pm 0.01^{\mathrm{a}}$ & $3.67 \pm 0.02^{\mathrm{a}}$ & $3.29 \pm 0.03^{\mathrm{a}}$ & $3.92 \pm 0.02^{\mathrm{a}}$ \\
\hline
\end{tabular}

Results are presented as mean $\pm \mathrm{SE}(\mathrm{n}=3)$. Mean values with different superscripts in the same row are significantly different $(\mathrm{p}<0.05)$

Moisture, ether extract and ash content were not influenced by dietary protein levels and they did not vary significantly among dietary treatments.

The proteolytic enzymes (proteases, trypsin and chymotrypsin) and ACP activities were significantly $(p<0.05)$ different among dietary treatments (Table 4). Fish fed with $45 \%$ protein level was found to have the highest protease, trypsin and chymotrypsin activities and lowest activity was found in fish fed at $25 \%$ protein level. As dietary protein level in the diet was raised up to $45 \%$ the activities of proteolytic enzymes were found to increase and thereafter declined significantly $(\mathrm{p}<0.05)$ with further increase in protein levels.

Significant difference $(p<0.05)$ in the activity of amylase was observed with different dietary treatments. Though the activities of lipase and ALP slightly increased with increase in dietary protein levels, the difference was not significant $(p>0.05)$. An increasing trend was observed in the activity of ACP which responded significantly $(p<0.05)$ to increase in dietary protein levels, except in $50 \%$ protein diet, where the activity of enzyme was decreased.

It is well known that protein is an expensive and the most important nutrient for feed formulation (Wee and Tacon, 1982; Zehra and Khan, 2011). In the present study, growth (weight gain and SGR) and survival of pengba increased significantly $(p<0.05)$ with increase in dietary protein levels from 25 to $45 \%$, and thereafter decreased at $50 \%$ protein level. Similar results were observed in various fish species such as Labeo rohita (Debnath et al., 2007); Puntius gonionotous (Mahanta et al., 2008) where the growth levels varied with different levels of protein content in the diets.

In the present study, the best growth performance, survival and feed utilisation of fish were achieved at $45 \%$ protein level than in other dietary treatments. Form the results of the present study, it was inferred that the feed with $45 \%$ protein level was utilised efficiently and resulted in maximum growth $(\mathrm{p}<0.05)$ and had lower FCR. These results are supported by earlier study that protein requirement of Carassius auratus was between 40-55\% (Fiogbe and Kestemont, 1995). Further, the present findings are supported by Basudha et al. (2001) who reported that growth performance of pengba was higher in fish fed with $40 \%$ protein level. However, protein utilisation of pengba observed in the present study is higher than the range determined in the common carp Cyprinus carpio (35-42\%) (Tacon, 1987).

Lesser protein content in the fish diets always results in negative impact on growth. Maximum protein in the diet is used for growth (protein synthesis) and the remaining protein which is unutilised, will be transformed as waste. In the present study, fish growth was found lowest in fish fed with 25 to $30 \%$ protein levels, as most of the protein in the diet was used for metabolic activity and repair

Table 4. Digestive enzyme activity in the intestine of Osteobrama belangeri fed at different protein levels

\begin{tabular}{lllllll}
\hline \multirow{2}{*}{ Enzymes } & \multicolumn{5}{c}{ Protein levels (\%) } \\
\cline { 2 - 7 } & 25 & 30 & 35 & 40 & 45 & 50 \\
\hline Protease & $8.38 \pm 0.36^{\mathrm{a}}$ & $9.71 \pm 0.34^{\mathrm{b}}$ & $12.11 \pm 0.23^{\mathrm{c}}$ & $16.41 \pm 0.35^{\mathrm{e}}$ & $20.56 \pm 0.28^{\mathrm{f}}$ & $14.18 \pm 0.09^{\mathrm{d}}$ \\
Trypsin & $6.57 \pm 0.06^{\mathrm{a}}$ & $8.33 \pm 0.01^{\mathrm{b}}$ & $10.49 \pm 0.09^{\mathrm{d}}$ & $12.35 \pm 0.03^{\mathrm{e}}$ & $14.48 \pm 0.12^{\mathrm{f}}$ & $9.85 \pm 0.02^{\mathrm{c}}$ \\
Chymotrypsin & $4.61 \pm 0.02^{\mathrm{a}}$ & $6.40 \pm 0.03^{\mathrm{b}}$ & $9.62 \pm 0.03^{\mathrm{c}}$ & $11.18 \pm 0.08^{\mathrm{d}}$ & $13.48 \pm 0.09^{\mathrm{e}}$ & $9.45 \pm 0.02^{\mathrm{c}}$ \\
Amylase & $14.18 \pm 0.01^{\mathrm{c}}$ & $12.91 \pm 0.01^{\mathrm{bc}}$ & $12.42 \pm 0.07^{\mathrm{bc}}$ & $11.99 \pm 0.39^{\mathrm{b}}$ & $11.66 \pm 0.30^{\mathrm{b}}$ & $9.60 \pm 0.30^{\mathrm{a}}$ \\
Lipase & $0.66 \pm 0.01^{\mathrm{a}}$ & $0.65 \pm 0.05^{\mathrm{a}}$ & $0.73 \pm 0.01^{\mathrm{a}}$ & $0.75 \pm 0.02^{\mathrm{a}}$ & $0.81 \pm 0.04^{\mathrm{ab}}$ & $0.73 \pm 0.03^{\mathrm{a}}$ \\
ALP & $12.34 \pm 0.08^{\mathrm{a}}$ & $12.59 \pm 0.05^{\mathrm{a}}$ & $13.06 \pm 0.02^{\mathrm{a}}$ & $13.42 \pm 0.05^{\mathrm{a}}$ & $13.49 \pm 0.30^{\mathrm{a}}$ & $13.19 \pm 0.02^{\mathrm{a}}$ \\
ACP & $8.77 \pm 0.04^{\mathrm{a}}$ & $10.65 \pm 0.21^{\mathrm{b}}$ & $13.37 \pm 0.07^{\mathrm{c}}$ & $17.70 \pm 0.18^{\mathrm{e}}$ & $20.37 \pm 0.09^{\mathrm{f}}$ & $16.93 \pm 0.01^{\mathrm{d}}$ \\
\hline
\end{tabular}

Proteolytic enzymes expressed in micromol of tyrosine released per min per $\mathrm{g}$ protein $\left(\mu \mathrm{m}\right.$ tyrosine min $^{-1} \mathrm{~g}_{\text {protein }}{ }^{-1}$ ); amylase expressed as $\mu \mathrm{m}$ maltose $\mathrm{min}^{-1} \mathrm{~g}$ protein; lipase quantifed as units $\mathrm{mg}$ protein ${ }^{-1}$; ALP and ACP are expressed in nanomoles p-nitrophenol released (nm p-nitrophenol $\mathrm{min}^{-1} \mathrm{mg}$ protein ${ }^{-1}$ ) at $37^{\circ} \mathrm{C}$; Means with different superscripts in the same row are siginificantly different $(\mathrm{p}<0.05$ ). 
making it unavailable for growth. Although, the growth indices increased significantly $(\mathrm{p}<0.05)$ with increase in dietary protein levels up to $45 \%$, the same were found to decrease at $50 \%$ protein level. These findings were supported by Mohanta et al. (2008) who reported that growth rate may vary at higher protein levels in Puntius gonionotus. When a high protein diet is supplied, mostly it gives rise to energy for maintainance of the body (Winfree and Stickney, 1981), which ultimately reduces protein utilisation in fish (Lee and Putnam, 1973).

FCR and PER siginificantly $(\mathrm{p}<0.05)$ improved from 25 to $45 \%$ protein levels. Several studies showed that whenever high levels of protein is supplied in the diet, the level of nutrient utilisation decreased, and feed consumption is reduced. The requirement of nutrients for optimum growth are always more than the requirement for optimal production (Siddiqui and Khan, 2009; Hossain et al., 2012). FCR was found to be the lowest at $45 \%$ protein level compared to all other dietary treatments. It is assumed that the optimum utilisation of protein and maximum growth in pengba could be achieved at $45 \%$ protein level. Further, as protein levels increased above $45 \%$, the FCR value increased. It might be due to poor utilisation of dietary protein at higher protein levels and imbalance of protein to energy ratio. These findings are similar to the reports of Salhi et al. (2004) in Rhamdia quelen and Mohanta et al. (2008) in Puntius gonionotus. PER was found to decrease significantly $(\mathrm{p}<0.05)$ as the protein level in the diet increased. The present study supports the findings of other workers in rohu (Gangadhara et al., 1997), catla (Murthy and Naik, 2000) and olive flounder (Kim et al., 2004).

In the current study, significant variation in crude protein content of fish $(\mathrm{p}<0.05)$ was observed in fish fed different dietary protein levels, which revealed that conversion and deposition of protein in the whole body increased withan increase in dietary protein level. Theresults of the study is supported by findings of several researchers in different fish species (Lazo et al., 1998; Doos Ali Vand et al., 2014). Insignificantly different variation in moisture, ether extract and ash content of fish between the dietary treatments was recorded. The results were supported by earlier studies on pengba fingerlings (Basudha et al., 2001, 2002). In earlier studies, ether extract and moisture content showed inverse relationship in rohu fed with varying dietary protein levels (Debnath et al., 2007). In the present study, protein levels of fish did not show any effect on ether extract and moisture contents and no such correlation was observed.
Growth pattern and protein levels in the diet are negatively correlated (Kohla et al., 1992), which depends on various biological and environmental factors. Therefore, to study the optimum nutrient requirement of fish, profile of digestive enzyme activities are often studied (Debnath et al., 2007; Gonza'lez-Fe'lix et al., 2010). Therefore, in the present study, digestive capacity of pengba was studied to optimise the dietary protein levels. Significant $(p<0.05)$ changes were noticed in the digestive enzyme activites in the intestine of pengba in relation to dietary protein levels, with some exceptions.

The proteolytic enzyme activity of juveniles of pengba was found to increase at dietary protein levels above $25 \%$. Significant $(p<0.05)$ increase in the activity of protease, trypsin and chymotrypsin was recorded with increase in dietary protein levels. In contrast, LopezLopez et al. (2005) reported that protease activity and dietary protein levels were not correlated with growth performance of fish. In seabass juveniles, the activity of trypsin was found to be unresponsive to protein diets (Cahu and Zambonino Infante, 1994). The activities of proteolytic enzymes increased with increase in dietary protein up to $45 \%$ and thereafter declined in fish fed with $50 \%$ protein diet. The results are in line with with the earlier reports that high acid proteolytic activity of gut content of sea bream (Diplodus puntazzo) juveniles can be correlated to the high protein content (Savona et al., 2011) and the presence of highly indigestible carbohydrate content in the diet which further reduced the proteolytic activity (Falge et al., 1978, Mohanta et al., 2008).

In general, protein hydrolysis is effected by proteases subsequently combined with trypsin and chymotrypsin when the food reaches intiestine. Trypsin and chymotrypsin are activated by trypsinogen and chymotrypsinogen in the intestine which are involved in the digestion of food particles (Ueberschar, 1993). In the present study increase in typsin and chymotrypsin activity with respect to increase in protein level in the diet, demonstrated that these two enzymes are hightly specific and helped in digestion of protein content in the intestine of pengba.

In general, amylase activity will be highest in and lower in carnivorous fishes (Sabapathy and Teo, 1993; Hidalgo et al., 1999). The activity of amylase was significantly high $(p<0.05)$ at $25 \%$ level of dietary protein and it decreased with increase in protein levels. The results were in contrast to earlier studies of Plantikow (1981) in rainbow trout (Oncorhynchus mykiss) and Debnath et al. (2007) in rohu (Labeo rohita) who reported that amylase activity was found to increase in fish fed with increased levels of dietary protein. The decreased 
levels of carbohydrates with increase in dietary protein levels, could be attributed to the decreased activity of amylase in the present study. The results are supported by the findings of Mohanta et al. (2008) in P. gonionotus fingerlings and Das and Tripathi (1991) in grass carp, Ctenopharyngodon idella. When the optimal level of protein in the diet is exceeded, enzyme activities slowly decrease (Ceccaldi, 1997). The activity of amylase is always influenced by other factors such as gut content (Kohla et al., 1992; Bhilave et al., 2014), the feeding habit (NRC, 1993; Sabapathy and Teo, 1993; Ismat et al., 2013), temperature and season (Kuz'mina et al., 1996) than the carbohydrate sources.

Lipase activity varied with different dietary protein levels. The acitivity was found to be within the range of 1.22-1.52 units mg protein ${ }^{-1}$ and was insignificantly $(p>0.05)$ different among dietary protein levels. Similar results were found in the studies conducted by Lundstedt et al. (2004) in juvenile pintado and Debnath et al. (2007) in rohu. Moreover, lipase activity was found higher in carnivorous fish as they consume rich fat in their diet (Chakrabarti et al., 1995).

Activity of alkaline phosphatase (ALP) is an indicator for nutrient absorption in epithelial layers (Harpaz and Uni, 1999; Gawlicka et al., 2000). Pengba has lesser ALP activity when compared to other herbivorous fishes (Harpaz and Uni, 1999). In this experiment, ALP activity was not significantly influenced by the different dietary treatments, but slightly increased with increase in dietary protein levels and similar results have been reported in Atlantic cod (Lemieux et al., 1999). The activity of acid phosphatase (ACP) showed significant variations and increased gradually with increase in dietary protein levels. The increased growth rate and ACP activity of fish positively responded with increase in dietary protein levels and similar results of increasing activity of ACP in rohu fed high protein diets have been reported by Debnath et al. (2007).

The enhanced proteolytic enzyme activities in response to protein utilisation observed in the present study, clearly demonstrated that early fry of pengba required high protein diet for optimum growth and survival.

\section{Acknowledgments}

The authors express their gratitude to Dr. W. S. Lakra, former Director, ICAR-CIFE, Mumbai, India for providing all the facilities to carry out the research work and ICAR, New Delhi, India for financial support.

\section{References}

Akpinar, Z., Sevgili, H., Ozgen, T., Demir, A. and Emre, Y. 2012. Dietary protein requirement of juvenile shi drum, Umbrina cirrosa (L). Aquac. Res., 43: 421-429.
AOAC 2003. Official methods of analysis, $15^{\text {th }}$ edn. Association of Official Analytical Chemists, Inc., Arlington, VA.

Basudha, C. H. and Vishwanath, W. 1999. Food and feeding habits of an endemic carp, Osteobrama belangeri (Val.) in Manipur. Indian J. Fish., 46: 71-77.

Basudha, C. H. and Vishwanath, W. 2001. Growth and feed utilisation efficiency of Osteobrama belangeri fed diets containing different levels of protein. Fish. Technol., 8: $110-114$.

Basudha, C. H. and Vishwanath, W. 2002. Nutritional evaluation of chicken gut and snail meat in diets of Osteobrama belangeri (Val.). Indian J. Fish., 49: 211-215.

Bhilave, M. P., Nalawade, V. B. and Kulkarni, J. J. 2014. Amylase activity of fingerlings of freshwater fish Labeo rohita fed on formulated feed. Int. J. Fish. Aquat. Stud., 2(1): 53-56.

Cahu, C. L. and Zambonino Infante, J. L. 1994. Early weaning of seabass (Dicentrarchus labrax) larvae with a compound diet: effect on digestive enzymes. Comp. Biochem. Physiol., 109A: 213-222.

Chakrabarti, I., Gani, M. D. A., Chaki, K. K., Sur, R. and Misra, K. K. 1995. Digestive enzymes in 11 freshwater teleost fish species in relation to food habit and niche segregation. Comp. Biochem. Physiol., 112A: 167-177.

Ceccaldi, H. J. 1997. Anatomy and physiology of the digestive system. In: D'abramo, L. R., Conklin, D. E. and Akiyama, D. M. (Eds.), Crustacean nutrition, The World Aquaculture Society, Lousiana, US. p. 261-291.

Das, K. M. and Tripathi, S. D. 1991. Studies on the digestive enzymes of grass carp, Ctenopharyngodon idella (Val.). Aquaculture, 92: 21-32.

Debnath, D., Pal, A. K., Sahu, N. P., Yengkokapm, S., Barauh, K., Choudhury, D. and Venkateshwarlu, G. 2007. Digestive enzymes and metabolic profile of Labeo rohita fingerlings fed diets with different crude protein levels. Comp. Biochem. Physiol., 146B: 107-114.

Doos Ali Vand, Z., Alishahi, M. and Tabande, M. R. 2014. Effects of different levels of Lactobacillus casei as probiotic on growth performance and digestive enzymes activity of Barbus gryprus. Int. J. Biosci., 4(7): 106-116.

Falge, R., Schpanol, L. and Jurss, K. 1978. Amylase, esterase and protease activity in the intestine content of rainbow trout Salmo gairdneri (Rich), after feeding with feed containing different amounts of starch and protein. J. Ichthyol., 18: 283-287.

Fiogbe, E. D. and Kestemont, P. 1995. An assessment of the protein and amino acid requirements in goldfish (Carassius auratus) larvae. J. Appl. Ichthyol., 11: 282-289.

Gangadhara, B., Nandeesha, M. C., Varghese, T. J. and Keshavanthan, P. 1997. Effect of varying protein and lipid levels on the growth of rohu, Labeo rohita. Asian Fish. Sci., 10: $139-147$. 
Garen, A. and Levinthal, C. A. 1960. Fine structure, genetic and chemical study of enzyme alkaline phosphatase of E. coli. Purification and characterisation of alkaline phosphatase. Biochim. Biophys. Acta, 38: 470-483.

Gawlicka, A., Parent, B., Horn, M. H., Ross, N., Opstad, I. and Torrissen, O. J. 2000. Activity of digestive enzymes in yolksac larvae of Atlantic halibut (Hippoglossus hippoglossus): indication of readiness for first feeding. Aquaculture, 184: 303-314.

Gonzalez-Felix, M. L., Castillo-Yanez, F. J., Ocano-Higuera, V. M., Perez-Velazquez, M., Cota-Moreno, V. and Lozano- Taylor, J. 2010. Effect of dietary protein source and time on alkaline proteolytic activity of Nile tilapia (Oreochromis niloticus). Fish Physiol. Biochem., 36: 779-785.

Harpaz, S. and Uni, Z. 1999. Activity of intestinal mucosal brush border membrane enzymes in relation to the feeding habits of three aquaculture fish species. Comp. Biochem. Physiol., 124A: $155-160$.

Hidalgo, M. C., Urea, E. and Sanz, A. 1999. Comparative study of digestive enzymes in fish with different nutritional habits. Proteolytic and amylase activities. Aquaculture, 170: 267-283.

Hofer, R. and Kock, G. 1989. Method for quantitative determination of digestive enzymes in fish larvae. Pol. Arch. Hydrobiol., 36: 439-441.

Hossain, M. A., Sultana, Z., Kibria, A. S. M. and Azimuddin, K. M. 2012. Optimum dietary protein requirement of a Thai Strain of Climbing Perch, Anabas testudineus (Bloch, 1792) fry. Turk. J. Fish. Aquat. Sci., 12: 217-224.

Ismat, N., Ashrar, M., Naeem, M. and Hafeez, M. 2013. Effect of different feed ingredients on growth and level of intestinal enzyme secretions in juvenile Labeo rohita, Catla catla, Cirrhinus mrigala and Hypophthalamicthys molitrix. Int. J. Aquac., 3(16): 85-91.

Kaushik, S. J., Doudet, T., Medale, F., Aguirre, P. and Blanc, D. 1995. Protein and energy needs for maintenance and growth of Nile tilapia (Oreochromis niloticus). J. Appl. Ichthyol., 11: 290-296.

Kim, K. W., Wang, X., Choi, S. M., Park, G. J. and Bai, S. C. 2004. Evaluation of dietary protein-to-energy ratio in juvenile olive flounder Paralichthys olivaceous (Temminck et Schlegel). Aquac. Res., 35: 250-255.

Kohla, U., Saint-Paul, U., Friebe, J., Wernicke, D., Hilge, V. and Braum, E. 1992. Growth, digestive enzyme activities and hepatic glycogen levels in juvenile Colossoma macropomum Cuvier from South America during feeding, starvation and refeeding. Aquac. Res., 23: 189-208.

Kunitz, M. 1947. Crystalline soybean trypsin inhibitor: II. General properties. J. Gen. Physiol., 30: 291-310.

Kuzmina, V. V., Golovanova, I. L. and Izvekova, G. I. 1996. Influence of temperature and season on some characteristics of intestinal mucosa carbohydrates in six freshwater fishes. Comp. Biochem. Physiol., 113B: 255-260.
Lazo, J. P., Davis, D. A. and Arnold, C. R. 1998. The effect of dietary protein level on growth, feed efficiency and survival of Florida pompano (Trachinotus carolinus). Aquaculture, 169: 225-232.

Lee, D. J. and Putnam, G. B. 1973. The response of rainbow trout to varying protein energy ratios in a test diet. J. Nutr., 103: 916-922.

Lemieux, H., Blier, P. and Dutil, J. D. 1999. Do digestive enzymes set a physiological limit on growth rate and food conversion efficiency in the Atlantic cod (Gadus morhua)?. Fish Physiol. Biochem., 20: 293-303.

Lopez-Lopez, S., Nolasco, H., Villarreal-Colmenares, H. and Civera-Cerecedo, R. 2005. Digestive enzyme response to supplemental ingredients in practical diets for juvenile freshwater crayfish Cherax quadricarinatus. Aquac. Nutr. 11: 79-85.

Lovell, R. T. 1989. Nutrition and feeding of fish. Van Nostrand Reinhold, New York, USA, 260 pp.

Lundstedt, L. M., Bibiano Melo, J. F. and Moraes, G. 2004. Digestive enzymes and metabolic profile of Pseudoplatystoma corruscans (Teleostei: Siluriformes) in response to diet composition. Comp. Biochem. Physiol., 137B: 331-339.

Mohanta, K. N., Mohanty, S. N., Jena, J. K. and Sahu, N. P. 2008. Protein requirement of silver barb, Puntius gonionotus fingerlings. Aquac. Nutr., 14: 143-152.

Murthy, H. S. and Naik, A. T. R. 2000. Effect of dietary protein and lipid levels on growth, survival and food conversion of Indian major carp (Catla catla). Isr. J. Aquac. Bamidgeh, 52: 70-76.

NRC 1993. Nutrient requirements of fish. National Academy Press, Washington, $114 \mathrm{pp}$.

Peres, A., Zambonino Infante, J. L. and Cahu, C. L. 1998. Dietary regulation of activities and mRNA levels of trypsin and amylase in sea bass (Dicentrarchus labrax) larvae. Fish Physiol. Biochem., 19: 145-152.

Plantikow, H. 1981. Amylaseaktivatat von Regenbogenforellen (Salmo gardineri Richardson) nach Akklimatisation an verschiedene Milieutemperaturen und-salinitaten and ihre Bedeutung fur die Kohlenhydratverdaulichkeit. IV. Wiss. Konf. Zu Fragen d. Physiol. Biol. und Parasitol. Von Nutzfischen, 2-6 September 1980, Rostock, p. 23-26.

Rick, W. and Stegbauer, H. P. 1974. Amylase measurement of reducing groups. In: Bergmeyer, H. V. (Ed.) Methods of enzymatic analysis, vol. 2., Academic Press, New York, p. $885-889$.

Sabapathy, U. and Teo, L. H. 1993. A quantitative study of some digestive enzymes in rabbitfish, Siganus canaliculatus and the seabass, Lates calcarifer. J. Fish Biol., 42: 595-602.

Salhi,M.,Bessonart,M.,Chediak,G.,Bellagamba,M.andCarnevia,D. 2004. Growth, feed utilisation and body composition of black catfish, Rhamdia quelen fry fed diets containing different protein and energy levels. Aquaculture, 23: 435-444. 
Savona, B., Tramati, C. and Mazzola, A. 2011. Digestive enzymes in larvae and juveniles of farmed sharpsnout seabream (Diplodus puntazzo) (Cetti, 1777). The Open Mar. Biol. J., 5: 47-57.

Siddiqui, T. Q. and Khan, M. A. 2009. Effects of dietary protein levels on growth, feed utilisation, protein retention efficiency and body composition of young Heteropneustes fossilis (Bloch). Fish Physiol. Biochem., 35: 479-488.

Tacon, A. G. J. 1987. The nutrition and feeding of farmed fish and shrimp. Food and Agriculture Organization of the United Nations, Brasilia. GCP/RAL/075/ITA, Field Document 2/E, $129 \mathrm{pp}$.

Ueberschar, B. 1993. Measurement of proteolytic enzyme activity: significance and application in larval fish research. In: Walther,
B. T. and Fuhn, H. J. (Eds.), Physiological and biochemical aspects of fish development, Norway, University of Bergen.

Wee, K. L. and Tacon, A. G. J. 1982. A preliminary study on the dietary protein requirement of juvenile snakehead (Channa micropeltes). Bull. Japan. Soc. Sci. Fish., 48: 1463-1468.

Wilson, R. P. and Halver, J. E. 1986. Protein and amino acid requirements of fishes. Ann. Rev. Nutr., 6: 225-244.

Winfree, R. A. and Stickney, R. R. 1981. Effects of dietary protein and energy on growth, feed conversion efficiency and body composition of Tilapia aurea. J. Nutr., 111: 1001-1002.

Zehra, S. and Khan, M. A. 2011. Dietary protein requirement for fingerling Channa punctatus (Bloch), based on growth, feed conversion, protein retention and biochemical composition. Aquac. Int., 20: 383-395.

Date of Receipt $\quad$ : 13.10 .2016

Date of Acceptance : 16.05 .2017 